\title{
Effect of Different Plant Growth Regulators and their Levels on Floral Yield and Vase Life of China Aster [Callistephus chinensis (L.) Nees] cv. Shashank
}

\author{
Mamilla Sindhuja $^{1}$, V.M. Prasad ${ }^{2}$ and Vinayak koradakera ${ }^{1}$ \\ ${ }^{1}$ (Ag.) Horti. (Floriculture and Landscaping), Department of Horticulture, \\ SHUATS, Allahabad, India \\ ${ }^{2}$ Department of Horticulture, SHUATS, Allahabad, India
}

*Corresponding author

\section{Keywords}

China aster, GA3, NAA, CCC, Flower yield and vase life

Article Info

Accepted:

26 December 2017

Available Online:

10 January 2018

\section{A B S T R A C T}

The present investigation entitled "Effect of different plant growth regulators and their levels on floral yield and vase life of China aster [Callistephus chinensis (L.) Nees] cv. Shashank" was under taken at Department of Horticulture, Naini Agriculture Institute, Sam Higginbottom university of Agriculture, Technology and Sciences (SHUATS), during the year 2016-17 with thirteen treatments which replicated thrice in a Randomized Complete Block Design. The treatments comprising of $\mathrm{GA}_{3}, \mathrm{NAA}, \mathrm{CCC}$ and their different concentrations along with control. The results of the study revealed that floral attributes like maximum flower diameter $(6.21 \mathrm{~cm})$, flower weight $(5.5 \mathrm{~g})$, flower yield per hectare $\left(12.58 \mathrm{t}\right.$ ) was observed from the plants grown in plots receiving $\mathrm{GA}_{3} @ 200 \mathrm{ppm}$. Among the treatments applied the minimum duration for bud initiation (51.67), minimum days to flowering (65.86) with maximum vase life (9.0 days) were recorded in CCC @ $1500 \mathrm{ppm}$. However maximum days taken to bud and flower initiation was recorded in control. Thus, it can be concluded that application of $\mathrm{GA}_{3} @ 200 \mathrm{ppm}$ can be recommended for commercial cultivation of China aster cv. Shashank.

\section{Introduction}

China aster [Callistephus chinensis (L.) Ness.] a member of the family Asteraceae, is one of the important commercial flower crops of our country. Among annual flower crops, it ranks next to chrysanthemum and marigold. The flowers assumed economic importance on account of their varied uses such as cut flowers for vase decorations, bouquets making, buttonholes, loose flowers for making garlands and religious functions. In garden, plants are used as bedding plants, making mixed herbaceous border and as a pot plants. In India China aster occupied approximately more than 5000 ha grown in few states like Maharastra, Karnataka, Tamil Nadu, West Bengal and Andhra Pradesh Chowdhuri et al., (2016). 
Apart from its multifarious uses, due to increased demand of China aster in domestic and international market as cut and loose flower and with shortage of supply at present, blooms of China aster are becoming attractive for growers as well as sellers. To meet the demand of high value cut flower crop of China aster, it is necessary to enhance the production both in quantitative and qualitative aspects. Growth regulators are used to overcome the factors limiting the growth and yield to harness maximum benefit. The most important plant growth regulators are the hormones auxin, gibberellin, ethylene, cytokinin, and abscisic acid. Other growth regulators often act by modifying the action of the natural hormones. It is realized that the exogenous application of growth regulators stimulate flowering, pollination, fertilization and seed setting to yield better quality seeds Padmalatha et al., (2015).

In the recent years, the growth regulators play a major role in overcoming the factors limiting the yield and quality for obtaining maximum benefit from seed production. It is realized that the exogenous application of growth regulators stimulate flowering, pollination, fertilization and seed setting to yield better quality seeds (Sunitha, 2007). Plant growth regulators are being increasingly used to manipulate the growth and flowering of ornamental plants. The plant growth regulators are compounds that in minor amounts modify the physiological processes of plants and ultimately alter the yield and quality. Numerous plant growth regulators have been widely used in many flowering plants and their efficacy have been demonstrated for nursery production, foliage plants and many other ornamental plants

\section{Materials and Methods}

The present investigation entitled "Effect of different plant growth regulators and their levels on floral yield and vase life of China aster [Callistephus chinensis (L.) Nees] cv. Shashank" was carried out under Allahabad agro climatic conditions at the experimental field of the Department of Horticulture, Allahabad school of Agriculture, Sam Higginbottom University of Agriculture, Technology and Sciences, Allahabad (U.P) in the month of November to March during the Rabi season of the year 2016-2017. It is located on latitude of $20^{\circ}$ and $15^{\circ}$ North and longitude of $60^{\circ}$ and $3^{\circ}$ East and at an altitude of 98 meters above mean sea level (MSL). The experimental plot was homogenous in fertility having assured irrigation and other required facilities. The soil of experimental field had sandy loam texture, acidic $\mathrm{pH} 7.2$ and organic carbon content $0.44 \%$.

The experiment was laid out in randomized complete block design with three replications. The thirteen treatments comprised of control, $\mathrm{GA}_{3}(50,100,150$ and $200 \mathrm{ppm}$ respectively), NAA (50, 100, 150 and $200 \mathrm{ppm})$ and CCC (500, 1000, 1500 and 2000 ppm respectively). One month old uniform sized seedlings of China aster were transplanted at a spacing of $40 \mathrm{~cm} \times 60 \mathrm{~cm}$ with a twelve plants in each plot. Solutions of $\mathrm{GA}_{3}$, NAA and $\mathrm{CCC}$ at different concentrations were prepared in 1000 $\mathrm{ml}$ volumetric flask by dissolving calculated quantity of chemicals in small quantity of ethyl alcohol and then volume was made up to one litre with distilled water. The prepared solutions were sprayed uniformly over the treatments immediately after preparation at 15 and 30 days after transplanting. Observations on different flowering attributes and quality were recorded and analyzed statistically.

\section{Results and Discussion}

Floral parameters like maximum flower diameter $(6.21 \mathrm{~cm})$, flower weight $(5.5 \mathrm{~g})$, flower yield per hectare (12.58 t) respectively the best results was recorded by the 
application of $\mathrm{GA}_{3}$ at $200 \mathrm{ppm}$. Apart from this CCC also showed the best results in terms of minimum duration for bud initiation $\mathrm{T}_{11}$
(51.67 days), minimum days to flowering $\mathrm{T}_{11}$ (65.86 days) and with maximum vase life $\mathrm{T}_{11}$ (9.00 days).

Table.1 Effect of different plant growth regulators on Number of days required for flowering of China aster cv. Shashank

\begin{tabular}{|c|c|c|c|c|}
\hline Treatments & $\begin{array}{c}\text { Days to first } \\
\text { bud initiation }\end{array}$ & $\begin{array}{c}\text { Days to 50\% } \\
\text { bud initiation }\end{array}$ & $\begin{array}{c}\text { Days to first } \\
\text { flowering }\end{array}$ & $\begin{array}{c}\text { Days to 50\% } \\
\text { flowering }\end{array}$ \\
\hline $\mathrm{T}_{0}$ & 63.76 & 74.15 & 80.9 & 86.3 \\
\hline $\mathrm{T}_{1}$ & 54.26 & 64.83 & 70.3 & 75.46 \\
\hline $\mathrm{T}_{2}$ & 55.64 & 66.72 & 71.76 & 77.08 \\
\hline $\mathrm{T}_{3}$ & 57.63 & 68.18 & 73.6 & 78.20 \\
\hline $\mathrm{T}_{4}$ & 58.22 & 70.09 & 74.93 & 79.7 \\
\hline $\mathrm{T}_{5}$ & 57.52 & 71.59 & 77.063 & 82.73 \\
\hline $\mathrm{T}_{6}$ & 58.80 & 72.81 & 78 & 83.96 \\
\hline $\mathrm{T}_{7}$ & 60.98 & 73.55 & 79.3 & 84.36 \\
\hline $\mathrm{T}_{8}$ & 61.47 & 73.64 & 78.26 & 85.26 \\
\hline $\mathrm{T}_{9}$ & 53.83 & 62.73 & 67.63 & 72.76 \\
\hline $\mathrm{T}_{10}$ & 53.23 & 63.42 & 68.93 & 73.8 \\
\hline $\mathrm{T}_{11}$ & 51.67 & 60.61 & 65.86 & 70.54 \\
\hline $\mathrm{T}_{12}$ & 52.81 & 61.88 & 66.4 & 71.2 \\
\hline S.Ed.( & 1.18 & 0.70 & 1.40 & 0.90 \\
\hline C.D.at 5\% & 2.44 & 1.45 & 2.89 & 1.86 \\
\hline
\end{tabular}

Table.2 Effect of different plant growth regulators on floral characters, yield and quality parameters of china aster

\begin{tabular}{|c|c|c|c|c|}
\hline Treatments & $\begin{array}{c}\text { Flower } \\
\text { diameter }(\mathbf{c m})\end{array}$ & $\begin{array}{c}\text { Flower weight } \\
(\mathbf{c m})\end{array}$ & $\begin{array}{c}\text { Total flower } \\
\text { yield(t/ha) }\end{array}$ & Vase life (days) \\
\hline $\mathrm{T}_{0}$ & 3.46 & 2.93 & 3.17 & 6.73 \\
\hline $\mathrm{T}_{1}$ & 5.16 & 4.73 & 9.62 & 8.6 \\
\hline $\mathrm{T}_{2}$ & 5.43 & 4.9 & 10.26 & 8.7 \\
\hline $\mathrm{T}_{3}$ & 5.6 & 5.06 & 10.86 & 8.8 \\
\hline $\mathrm{T}_{4}$ & 6.21 & 5.5 & 12.58 & 8.96 \\
\hline $\mathrm{T}_{5}$ & 4.7 & 4.65 & 9.25 & 8 \\
\hline $\mathrm{T}_{6}$ & 4.7 & 4.7 & 9.82 & 7.8 \\
\hline $\mathrm{T}_{7}$ & 4.96 & 4.56 & 9.00 & 7.66 \\
\hline $\mathrm{T}_{8}$ & 4.8 & 4.36 & 8.27 & 7.5 \\
\hline $\mathrm{T}_{9}$ & 3.93 & 3.63 & 5.87 & 8.1 \\
\hline $\mathrm{T}_{10}$ & 3.71 & 3.9 & 6.91 & 8.83 \\
\hline $\mathrm{T}_{11}$ & 3.70 & 4.06 & 7.45 & 9 \\
\hline $\mathrm{T}_{12}$ & 3.54 & 3.75 & 6.44 & 8.33 \\
\hline S.Ed.( \pm () & 0.11 & 0.48 & 0.98 & 0.12 \\
\hline C.D.at 5\% & 0.23 & 0.98 & 2.01 & 0.26 \\
\hline
\end{tabular}


Figure.1 Effect of different plant growth regulators on Number of days required for flowering of China aster cv. Shashank

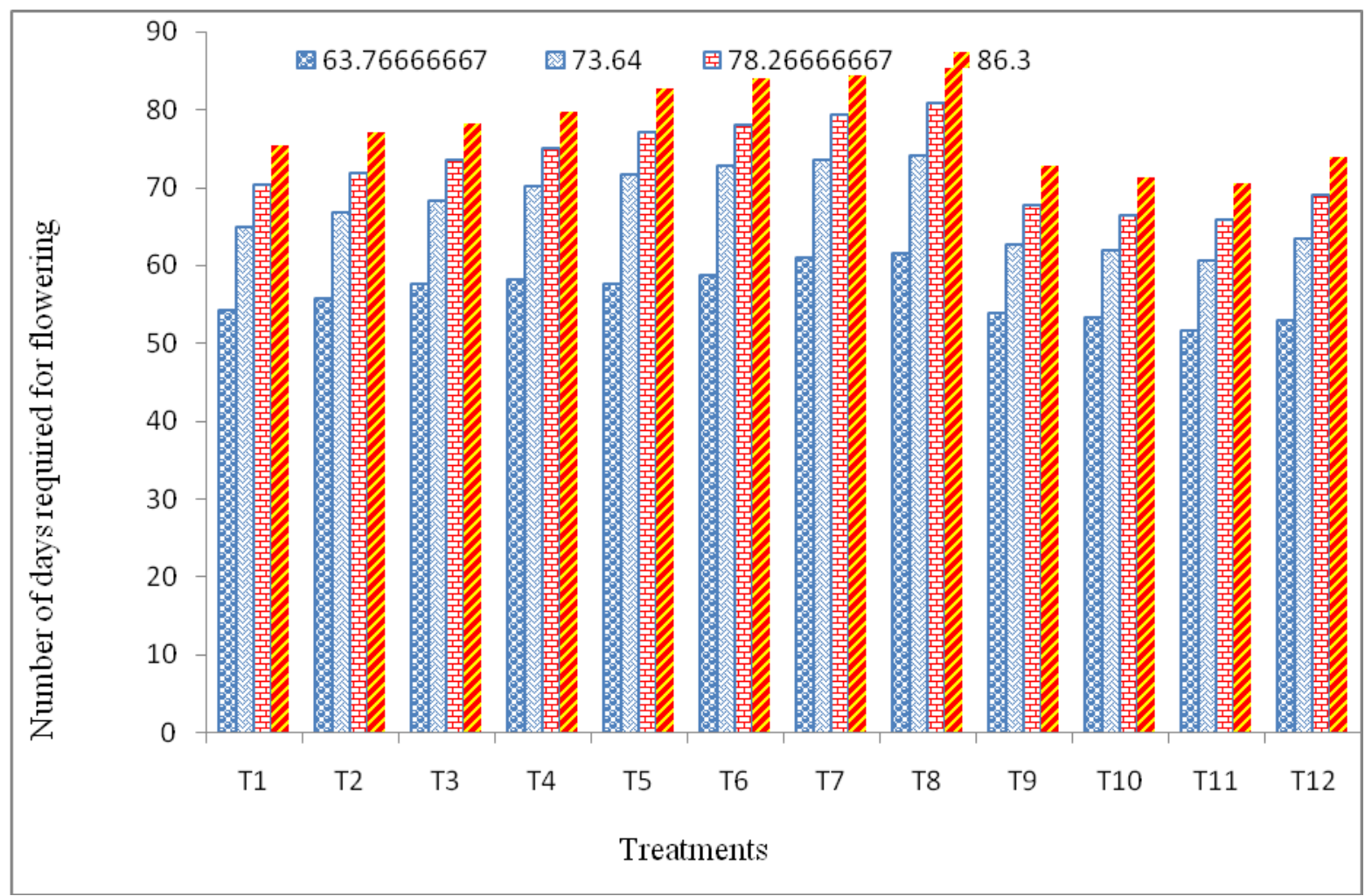

Figure.2 Effect of different plant growth regulators on Flower yield per hectare $(\mathrm{t} / \mathrm{h})$ of China aster cv. Shashank

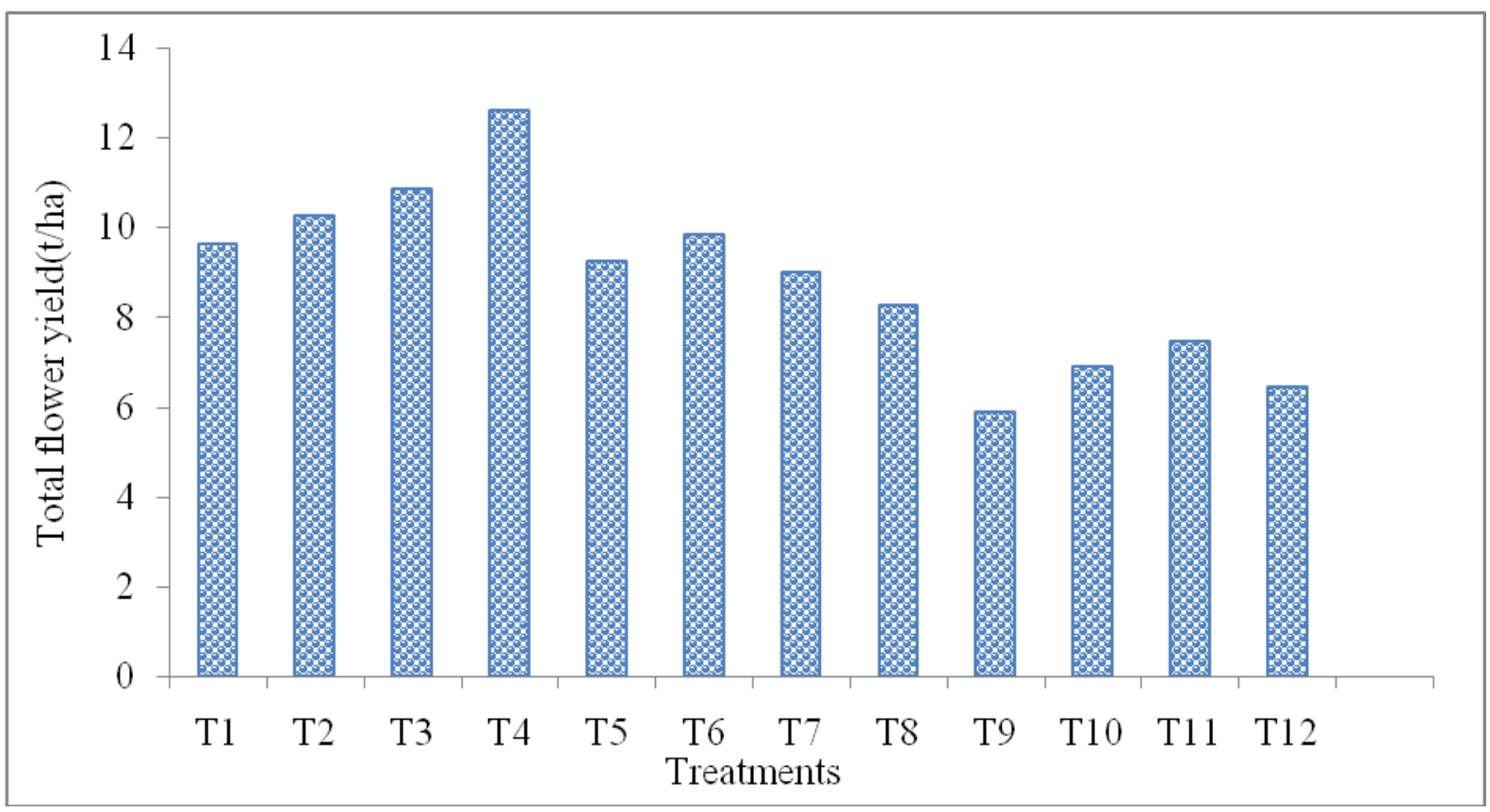


Figure.3 Effect of different Plant growth regulators on vase life (days) of China aster

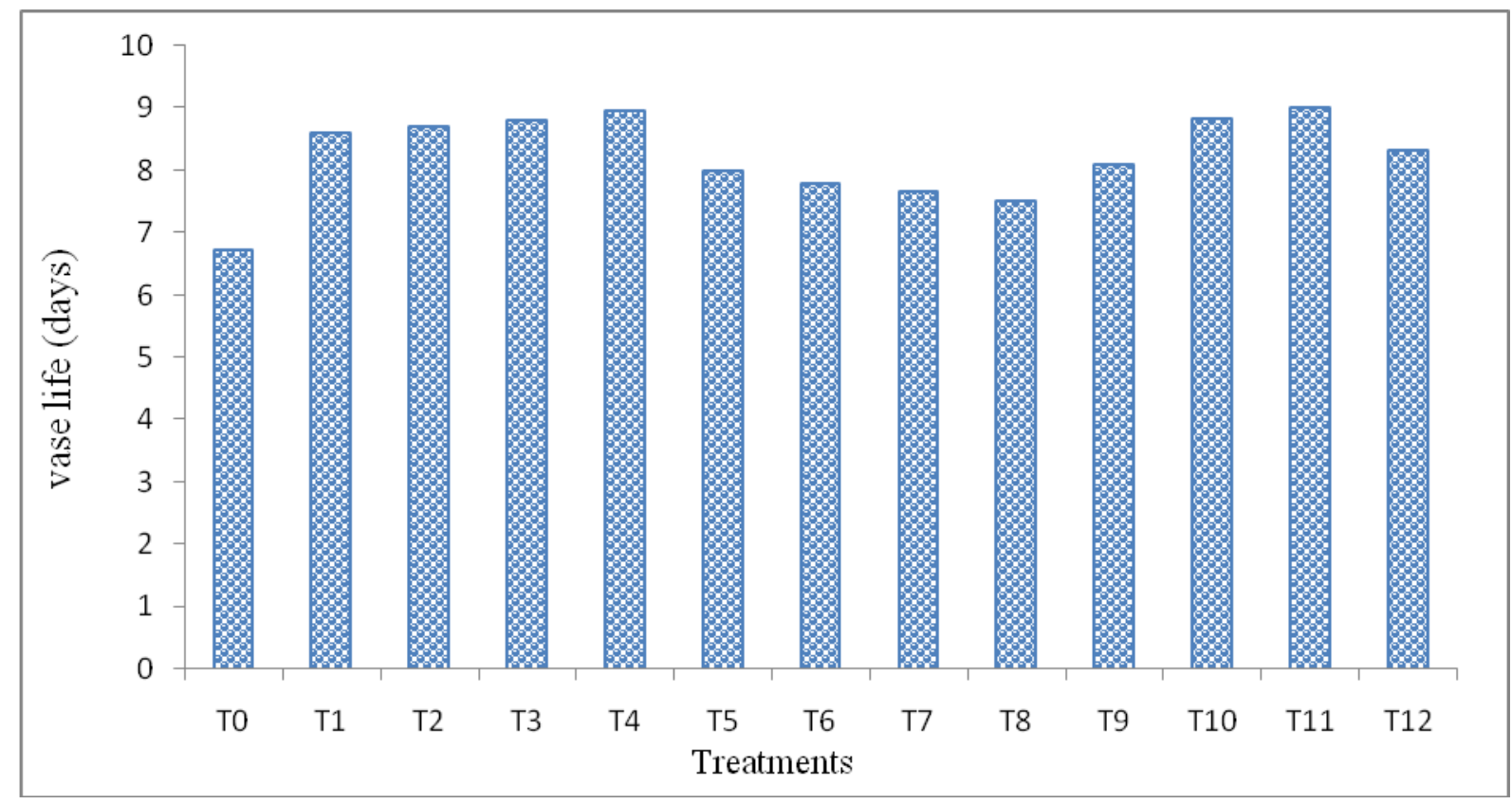

The reason for enhancement of flower size and diameter of flower might be due to increase in length of petals and pedicles and it was caused by drawing photosynthates to the flower as a consequence of intensification of sink it was reported by Sainath et al., (2014) in china aster, Patra et al., (2015) in gerbera and Palei et al., (2016) in African marigold.

Vase life and duration of bud initiation and minimum days to flowering might be due to growth retardants like cycocel. One of the greatest problems in post harvest flower physiology is the blockage of the vascular system. This blockage might be due to air or bacterial growth. Another cause of vascular blockage is the plants reactions to the actual cut. Even in the flower stem that is removed from the mother plant, certain enzymes are mobilized to the wounded area where chemicals are released in order to try to seal the wound (Loub and Van Doorn 2004). Similar results were also reported by Patil et al., (2013) in china aster, Kumar (2012) in china aster and Munikrishnappa et al., (2014) in china aster

\section{Acknowledgement}

I wish to express my sincere gratitude to $\mathrm{Mr}$. Dr. V.M. Prasad, Professor and Head, Department of Horticulture, SHUATS, Allahabad for providing me an opportunity to do my project work in Department of Horticulture, Naini Agriculture Institute, Sam Higginbottom university of Agriculture, Technology and Sciences (SHUATS), during the year 2016-17.

\section{References}

Chowdhuri, T.K, Rout, B, Sadhukhan R. and Mondal, $\mathrm{T}$ (2016). International Journal of Pharmaceutical Science Invention. Volume 5 Issue 8 PP. 15-18

Kumar, E.K (2012). Studies on the effect of plant growth regulators on growth, flower yield and vase life of china aster [Callistephus chinensis (L.) Ness.] cv. Kamini in coastal districts of Andhra Pradesh. M.Sc. (Hort.) thesis submitted to the Dr.Y.S.R Horticultural University, Tadepalligudem (AP). 
Loub and Van Doorn, G (2004). Woundinduced and bacteria-induced xylem blockage in roses, Astible, and Viburnum. Postharvest Biology and Technology. 32: 281-288.

Munikrishnappa, P.M. and S.Y. Chandrashekar (2014). Effect of growth regulators on growth and flowering of China aster (Callistephus chinensis L. Nees) Agri. Reviews. 35 (1): 57-63.

Patil, P.V, Patil S.D, Patil M.R and Kantharaju K.T. (2013). Effect of growth retardants on yield and vase life of China aster [Callistephus chinensis (L.) Nees.]. Trends in Life Sciences. 2(2): 55-56.

Pavan Kumar, K.T, Padmalatha, M. Pratap and S. Narender Reddy (2015). Effect of plant Bio-Regulators on Growth, Flowering and Seed yield in China aster (Callistephus chinensis L. Nees) CV. Kamini. Indian Journal of Agriculture Research. 49(4): 348-352.

Patra, S.K, S, Beura and T. Shasani (2015). Efficacy of GA3 on growth and flowering regulation of in vitro raised hybrid gerbera under shade net. Agriculture Science Digest. 35 (3): 173177.

Sainath, D.S, Uppar, V.S, Patil, V.K, Deshpande and Hunje R. (2014). Effect of different growth on seed yield and quality attributes in annual chrysanthemum (Chrysanthemum coronarium L.). Karnataka Journal of Agricultural Sciences. 27(2): 131-134.

Suvalaxmi Palei, A.K. Das and Dash, D. K. (2016) Effect of plant growth regulators on growth, Flowering and yield attributes of African marigold (Tagetes erecta L.) International Education \& Research Journal. 2454-9916, Volume : 2, Issue : 6 .

Sunitha, H.M, Ravi Hunje, Vyakaranahal, B.S. and Bablad H.B. (2007). Effect of plant spacing and integrated nutrient management on yield and quality of seed and vegetative growth parameters in African marigold (Tagetes erecta Linn.). Journal of ornamental horticulture. 10(4): 245-249.

\section{How to cite this article:}

Mamilla Sindhuja, V.M. Prasad and Vinayak koradakera. 2018. Effect of Different Plant Growth Regulators and their Levels on Floral Yield and Vase Life of China Aster [Callistephus chinensis (L.) Nees] cv. Shashank. Int.J.Curr.Microbiol.App.Sci. 7(01): 3391-3396.

doi: https://doi.org/10.20546/ijcmas.2018.701.401 